\section{Category}

Peptide Chemistry

\section{Key words}

native chemical ligation

amide bond

thioester link

polypeptides

proteins

L. E. CANNE*, S. J. BARK, S. B. H. KENT (THE SCRIPPS RESEARCH INSTITUTE, LA JOLLA, USA)

Extending the Applicability of Native Chemical Ligation

J. Am. Chem. Soc. 1996, 118, 5891-5896.

\title{
Extension of Native Chemical Ligation
}

Generalized native chemical ligation of unprotected peptide segments:

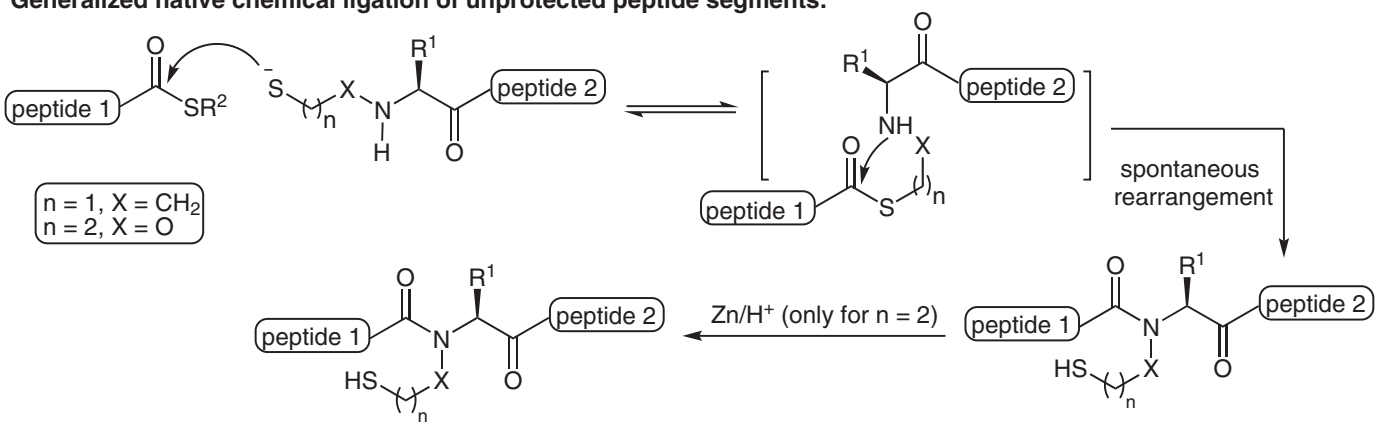

Synthesis of $\mathbf{N}^{\alpha}$ (substituted) peptide segments:

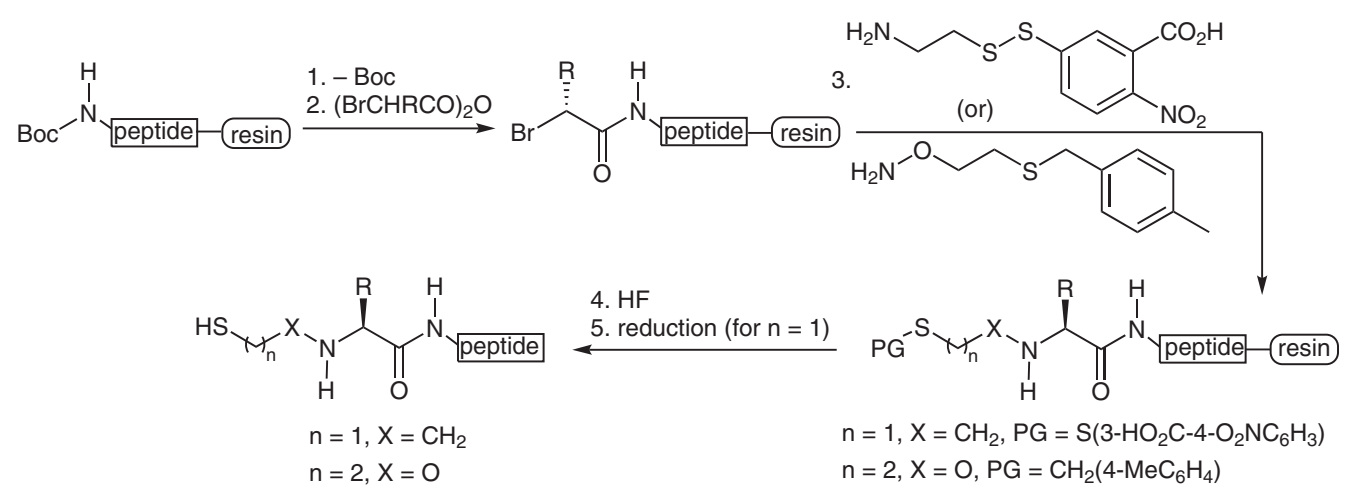

Synthesis of (aminooxy)ethanethiol derivative:<smiles>O=C1c2ccccc2C(=O)N1O</smiles><smiles>Cc1ccc(CSCCON2C(=O)c3ccc(CCBr)cc3C2=O)cc1</smiles><smiles>Cc1ccc(CSCCON)cc1</smiles>

Significance: The authors have extended the applicability of native chemical ligation (NCL) of unprotected peptide segments by the use of X-Gly and Gly-X ligation sites. This increases the number of suitable sites for NCL by a factor of three, to include more than 50 of the 400 dipeptide sequences found in proteins.
Comment: In this NCL method, the [peptide $\left._{1}\right]^{\alpha} \operatorname{COSR}$ reacts with a second peptide having an $\mathrm{N}^{\alpha}$-[(oxy)ethanethiol] group to afford the thioester-linked product, which rearranges to form a ligation product linked by an $\mathrm{N}$-substituted amide bond. In addition, the substitution on the amide bond can be removed by treatment with $\mathrm{Zn}$ in acidic medium. 